\title{
Opinions of Social Studies Teacher Education Students about the Impact of Environmental Education on Ecological Literacy
}

\author{
Esen DURMUS 1 \\ Firat University, Elazığ TURKEY
}

\author{
Müșerref Kübra KINACI ${ }^{2}$ \\ Furat University, Elazığ TURKEY
}

${ }^{1}$ Corresponding author: Assoc. Prof. . Firat University, Faculty of Education, Department of Social Studies Education, Elazı̆̆, TURKEY. esendurmus@firat.edu.tr. ORCID: 0000-0003-1011-8785

2 Ph.D. Firat University, Faculty of Education, Social Studies Education, Elazığ, TURKEY. kubrakinaci44@gmail.com. ORCID: 00000003-0918-3715

\begin{abstract}
In the century we live in, the level of environmental awareness, environmental knowledge, and ecological literacy of Social Studies teacher education candidates is of great importance to raise individuals who possess high ecological culture and environmental sensitivity. The research was carried out with a phenomenological pattern from qualitative research methods. The study group of research was determined by criterion sampling, which is a purposeful sampling method. The study group consists of 15 teacher education students who studied in the Department of Turkish and Social Sciences Education, Department of Social Studies Education and took the environmental education course in a Faculty of Education at a university in Turkey during the 2019-2020 academic years. The research data was obtained through a semi-structured interview form. The research data were analyzed by the content analysis method and evaluated with a qualitative data analysis program. One of the most important results obtained from this research includes that Social Studies teacher education students correctly perceive the concepts of Environmental Education and ecological literacy overall. Also, it is seen that Social Studies teacher education students stated that Environmental Education can provide development in their cognitive, affective, and behavioral dimensions such as information and increased consciousness about resource consumption, environmental awareness and sensitivity, problem-solving, understanding about sustainability, positive attitudes and behavioral development and changes and that will positively affect the ecological literacy levels of an individual. For this reason, the concepts of Environmental Education and ecological literacy should be emphasized because it is necessary for ecological literacy to be explained to the students and projects should be carried out accordingly
\end{abstract}

\section{Keywords}

Environmental Education, Ecological Literacy, Social Studies

To cite this article: Durmuş, E.; Kınacı, M. K. (2021). Opinions of social studies teacher education students about the impact of environmental education on ecological literacy. Review of International Geographical Education (RIGEO), 11(2), 482-501. doi: 10.33403rigeo.825516 
The relationship humans have with the environment and their effort to control the environment has caused some regional and global environmental problems (Sever \& Yalcınkaya, 2018, p. 16). As a result of the negative changes caused by human-induced problems in the ecosystem, various problems have emerged, such as contamination, and degradation of the earth's "atmosphere, water, and terrestrial" ecosystems, which may be almost impossible to repair (Garipağaoğlu, 2020 , p. 5). The emergence and spread of these problems vary depending on time, geographical space, and socio-cultural levels of societies. The emergence of environmental problems in different geographical places and societies is shaped by the cultural, scientific, and economic rules and values of that society, and this situation is perceived as an environmental threat (Atasoy, 2019, p. 51). Depending on this situation, concepts related to environmental problems and Environmental Education are more frequently on the scientific agenda, and it is no longer enough to develop only technology or some rules to overcome these problems which concern all nations (Kahyaoğlu, Daban \& Yangın, 2008; Sever \& Yalcınkaya, 2018). To solve this problem, communities on a global scale must be developed with environmental knowledge, skills, attitudes, and positive behaviors, to become aware about the environment and how to solve environmental problems (North American Association for Environmental Education [NAAEE], 2019). The impact of education is great in the development of environmental awareness, a love of nature, and an environmental sensitivity in children, especially in the transformation and transfer of permanent behavior to life (Atasoy, 2019, p. 153). This can only be achieved through widespread, achievable, stable, and quality Environmental Education programs aimed at protecting and improving the environment.

Environmental Education is defined as an education that enables an individual to protect nature and cultural values, and also be actively involved in solving environmental problems as well as improving environmental awareness in individuals, gaining environmental sensitivity, and reflecting them on in their behaviors (Güler, 2010, p. 32). Environmental Education with this definition is also expressed as a process that aims to train individuals who have knowledge and skills about the environment and environmental problems, to play an active role in solving environmental problems, and are willing to strive in this direction (Mercan, 2019, p. 373). In this way, Environmental Education aims to help a child establish a healthy connection between themselves and their natural environment by enabling them to recognize his environment through psychological, sociological, and behavioral rules (Atasoy, 2019, p. 103). For this reason, rather than traditional goals of Environmental Education, the focus should be on the process of Environmental Education which aims to develop skills and abilities that can reflect a sustainable lifestyle (Özdemir, 2007, p. 37). In short, Environmental Education, whose roots are based on protecting the education of nature and natural resources and reflects the needs of the age, is focused on protecting and improving the environment in a way that affects the entire ecosystem. Ecology, which explains the functioning of ecosystems, is, therefore, the basis of environmental education (Peyton, Campa, Winterstein, Peyton, \& Peyton, 1995, p. 5).

Environmental literacy came to the fore in the 1960s when Environmental Education began to gain importance. Environmental literacy, built on an ecological 
model, is the ability to perceive and interpret environmental systems and to take appropriate measures to ensure and improve these environmental systems in a healthy way (Roth, 1992, p. 7-8). Environmental literacy education is the basis of Environmental Education because raising environmental literacy individuals is among the most important objectives (Aydın, Dündar, \& Korkut, 2016; Dada, Eames, \& Calder, 2017). By conducting Environmental Education together with the concept of sustainability, the concept of environmental literacy has become the concept of "ecological literacy". Therefore, in the current study, environmental literacy was used synonymously with ecological literacy within the framework of sustainable living. Although the concepts of environmental literacy and ecological literacy are used interchangeably, there are some differences between them. While environmental literacy often acts with an understanding of Environmental Education aimed at gaining problem-solving skills, ecological literacy expresses a more comprehensive field of literacy that prioritizes the interaction of human and nature with a systematic approach and the acquisition of appropriate "cognitive, sensory and behavioral" situations (Özdemir, 2017, p. 14-19).

According to Roth (1992), the concept of ecological literacy benefits from six main areas in terms of environmental sensitivity: knowledge, skills, attitudes and personal investment, responsibility, and active participation (p. 9). One of the main objectives of Environmental Education is to inform the community about the environment, to raise awareness, to transform awareness into permanent behaviors, and to ensure that individuals take an active part in solving problems. These goals can only be carried out through ecological literacy training. Ecological literacy education, on the other hand, is defined as a field of study that allows the individual to realize they constitute part of the human-nature relationship and are a small part within the cycle of nature. The Social Studies lessons are also among the main courses where ecological literacy education can be taught (Aydın et al., 2016, p. 1160-1161). In this respect, the Social Studies lessons are seen as important in terms of addressing the human and environmental relationship in all dimensions in the context of the past, today, and the future; and aims to raise responsible citizens because good and responsible citizens are those who are sensitive to the environment, its environmental problems and play an active role in solving these problems (Karatekin, 2011b, p. 278). For this reason, it is understood that the Social Studies lessons addressing human and environmental interaction are very important and functional in terms of Environmental Education and ecological literacy education.

Social Studies teachers have a most crucial role to play in the field of Social Studies lessons, which have a very important function in Environmental Education. This is because they are teachers who will provide students with an ecological and environmental set of knowledge, skills, and behaviors. First of all, Social Studies teachers' success in Environmental Education depends on their individual ecological literacy levels for teachers to succeed in environmental education. For this reason, it is necessary to measure or determine both Environmental Education knowledge and environmental awareness of Social Studies teacher education candidates (Karatekin, 2011a, p. 3). It is also of great importance that teacher education candidates are ecologically literate and have sufficient knowledge about 
Environmental Education (Dada et al., 2017, p. 201). In this respect, it is very important to determine the environmental interests and attitudes of teacher education candidates who play an important role in providing positive cognitive, emotional, and behavioral situations related to the environment to individuals (Kahyaoğlu et al., 2008, p. 44-45). Accordingly, attention should be given to teacher education, and the professional qualifications of teachers in Environmental Education, and concepts about how to improve teachers should be clarified (Hart, 1987, p. 23). In addition, Environmental Education in universities should support teacher competencies and help teacher candidates to transfer their training to their students. Teacher education candidates should act in line with Environmental Education approaches that guide and direct students towards this field.

Today, incomplete or incorrect messages about humans, nature, and the environment can be sent to students due to reasons such as the location of schools, teacher qualifications, educational programs, ecological awareness, and environmental sensitivity. Obviously, for students to accurately perceive and understand nature, environment, and child relationships, the studies must be longterm and permanent (Atasoy, 2005, p. 93). In this respect, Environmental Education should not only be limited to the purpose of giving knowledge and responsibility but should also be reflected in behaviour (Kaya, Çobanoğlu, \& Artvinli, 2011, p. 412). Subjects and concepts such as awareness about unconscious resource consumption and environmental pollution, which prioritize sustainability for a good life in the future, should be passed on to students within the scope of Environmental Education in Social Studies lesson, and as a result their ecological literacy levels should increase (Bahar \& Kiras, 2017, p. 1704). In recent years, Environmental education and ecological literacy have been attracting considerable attention and studies on this subject are increasing (Ulu-Kalın, 2018, p. 223). Studies in the field of Environmental Education in Turkey are limited and remain theoretical (Karataş, 2018, p. 33).

When the literature is examined, studies in the field of Environmental Education and ecological literacy are generally seen to be mixed and quantitative (Adanalı \& Alım, 2019; Atasoy, 2005; Atasoy \& Ertürk, 2008; Erciş \& Türk, 2016; Kostova \& Atasoy 2008; Kurtdede-Fidan \& Thessali-Ay, 2016; Sahin, Ünlü, \& Ünlü 2016; Powell, Stern, Frensley, \& Moore, 2019). A study on the impact of Environmental Education on ecological literacy was carried out (Kıyıcl, Yiğit \& Darçın, 2014) however, there is no study in the literature on the opinions of Social Studies teacher education students about the effect of Environmental Education on ecological literacy. For this reason, it is thought that the research is important in terms of evaluating the effects of Environmental Education on ecological literacy with the opinions of Social Studies teacher education students.

The aim of the research is to reveal the knowledge and opinions of Social Studies students about the concepts of Environmental Education and ecological literacy. For this purpose, the following research questions were discussed:

1. How do Social Studies teacher education students define Environmental Education? 
2. What is ecological literacy according to Social Studies teacher education students?

3. According to Social Studies teacher education students, what are the effects of Environmental Education on the ecological literacy of an individual?

4. According to Social Studies teacher education students, what are the effects of Social Studies lessons on the ecological literacy of an individual?

\section{Methodology}

\section{Design of the Research}

This research, which aims at revealing Social Studies teacher education student opinions about the impact of Environmental Education on ecological literacy, was carried out with a phenomenology pattern, which is one of the qualitative research patterns. Phenomenology is a research pattern that provides an in-depth understanding of a case experienced by several individuals (Creswell, 2013/2020, p. 85). Phenomenology provides an appropriate research base for examining the cases that are not foreign but are not fully understood (Yıldırım \& Simsek, 2018, p. 69). A phenomenological study focuses on how people experience what they experience (Patton, 2000/2018, p. 107). In addition, participant selection, validity, and ethical issues are among the important elements of research design in phenomenology and contribute to the rigor of a phenomenological study (Cilesiz, 2011, p. 498).

\section{Study Group}

The study group for the research consisted of 15 Social Studies teacher education students, 5 of whom were men and 10 of whom were women. All participants studied in the Department of Social Studies Education in the Department of Turkish and Social Sciences Education in a Faculty of Education at a university in Turkey during the fall semester of the 2019-2020 academic years. Participants volunteered to participate in the study if they met the criteria for sampling from 2 rd grade Social Studies teacher education students who took the Environmental Education course.

The study group was determined by criterion sampling, which is one of the purposeful sampling strategies. "Purposive sampling allows for in-depth research by selecting information-rich situations depending on the purpose of the study." (Büyüköztürk et al., 2019, p. 90). Phenomenology uses the criteria sampling of participants that meet the predetermined criteria. The most obvious criterion is the participant's experience with the case examined (Moser \& Korstjens, 2018, p. 11). The criteria set here is that Social Studies teacher education students have taken the Environmental Education course. Eventually, researchers contacted second-grade Social Studies teacher education students who took Environmental Education and volunteered to participate in the research. Interviews were conducted face-to-face in an appropriate environment. Before starting the interview, each participant was given the necessary information about the research. The interviews took, on average, between 20-30 minutes to complete. 


\section{Data Collection Tools}

In the current research, a semi-structured interview form was used Interviews take place when researchers ask questions to one or more participants and record the answers given (Creswell, 2012/2019, p. 281).

A literature review was done and an interview form was prepared to create the interview form of the research. Then, the opinions of two faculty members from the Field of Social Studies Education in the Faculty of Education were taken by the researcher and the interview form was prepared with the arrangements made. In this research, the interview form consisted of four questions developed by researchers for Social Studies teacher education students, to achieve the determined goals of the research.

\section{Data Analysis}

A content analysis method was used to analyze the data. Content analysis is "a scientific approach that investigates the social reality by classifying the message contained in verbal, written and other materials objectively and systematically in terms of meaning and or grammar, transforming them into numbers and making inferences" (Tavşancll \& Aslan, 2001, p. 22).

A qualitative data analysis program was used to evaluate the research data. During the analysis, encodings were made based on the questions on the interview form, and themes were created by bringing these codes together consistently among themselves. To confirm whether the themes reached represent the reference sentences, the opinion of two faculty members from a Faculty of Education in the field of Social Studies Education were consulted. At the end of the evaluation, the themes were presented as models. These models were interpreted and supported by quotations from participant opinions.

\section{Validity and Reliability of Research}

A detailed report of the data collected as a result of the research and a detailed explanation of how the researchers reached the results is an important criterion for ensuring validity in a qualitative study (Yıldırım \& Şimşek, 2018, p. 270). To ensure the validity of the research, the data analysis process, i.e. themes, are explained and the themes obtained as a result of the research and the reference sentences for these themes are included in the findings section. Participant opinions on themes are indicated in italics in quotation marks with abbreviations such as S.1.Mrs/Mr (1st Student, Mrs/Mr) at the beginning.

To ensure the reliability of the research, coding was evaluated by research experts and researchers, and then the numbers of consensus and disagreement were determined by comparing these coding, and the reliability of the research was calculated. The reliability of the study was calculated according to Miles \& Huberman's formula " reliability = number of consensus/total consensus + number of disagreement," and the compliance between researchers was determined as 0.90 (1994/2019, p. 64). According to Saban (2009), reliability is ensured in qualitative research when the compliance between expert and researcher assessments is $90 \%$ or higher (p. 288). 
In order to ensure cogency, expert examinations were conducted and feedback were taken by people specializing in research and qualitative research methods. Criteria sampling strategy, which is a purposeful sampling strategy was intended to ensure transferability. Raw data were edited for a detailed description of the study, and direct citations were included and conveyed to the reader. In order to ensure consistency, the interviews were conducted and recorded with the participants, and were compared with the results of the research to examine consistency. Finally, to ensure verifiability, the results obtained by the researchers were compared with the raw data, and a confirmation review was conducted by an expert by evaluating the judgments, interpretations, and recommendations reached in the research (Yıldirım \& Simsek, 2018). In short, "cogency, transferability, consistency and verifiability" strategies expressed by Erlandson, Harris, Skipper \& Allen, (1993) were used to ensure validity and reliability in the research.

\section{Findings}

Four themes were identified for the opinions of Social Studies students on the impact of Environmental Education on ecological literacy. These themes are given as models in terms of "Environmental Education", "ecological literacy", "the effects of Environmental Education on the ecological literacy of an individual" and "the effects of Social Studies lessons on the ecological literacy of an individual".

\section{Findings on the Definition of Environmental Education}

The first of the themes identified by the opinions of Social Studies teacher education students on the impact of Environmental Education on ecological literacy relates to the definition of Environmental Education. Social Studies teacher education students' opinions about environmental education were taken, and it was determined that this theme has five sub-themes in line with these views. It was determined that Social Studies teacher education students define Environmental Education within the scope of awareness, protection, informing, sustainability and sensitivity. The model and frequency values for this theme are given in Figure 1.

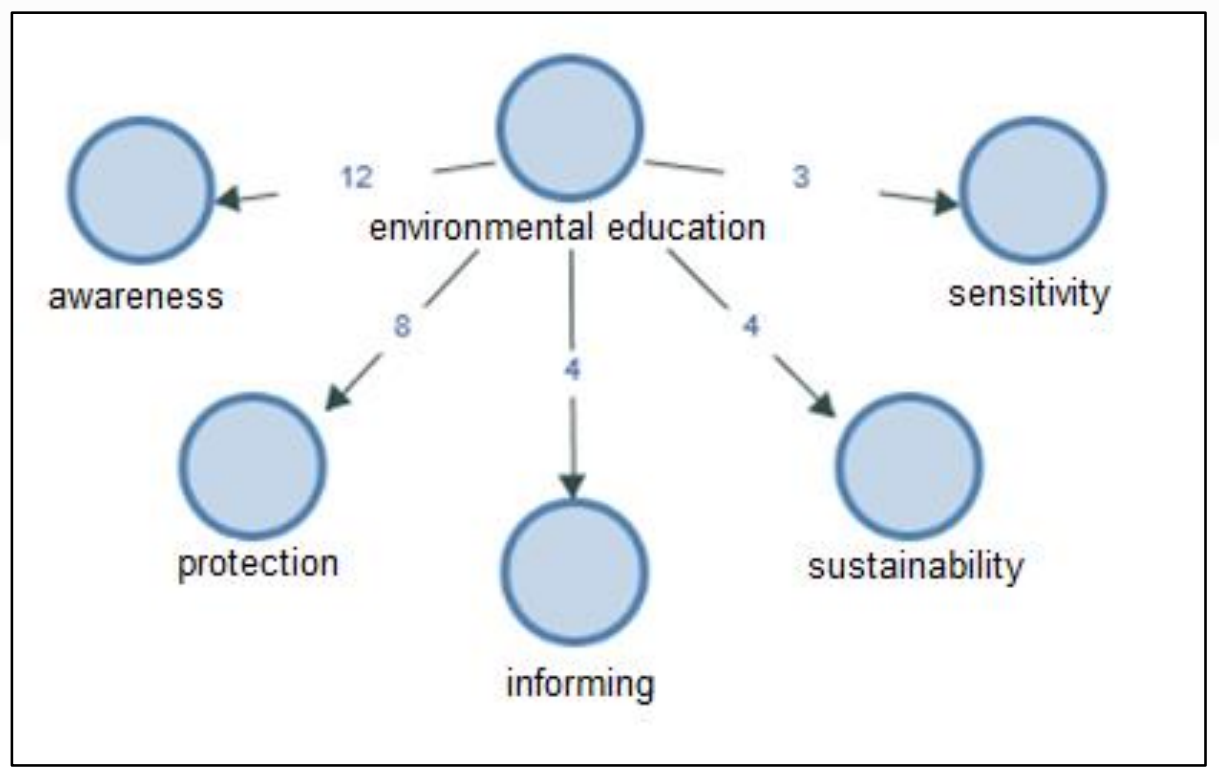

Figure 1. Model for the definition of environmental education 
When Figure 1 is examined, it is seen that the most loading in line with the opinions of Social Studies teacher education students regarding the definition of Environmental Education is directed towards the sub-theme of "raising awareness". Other sub-themes identified in the definition of Environmental Education are "protection", "informing", "sustainability," and "sensitivity". Below are some subthemes and participant opinions regarding these data.

One of the teacher education students who associated the theme of Environmental Education with the sub-theme of "raising awareness" stated her opinion saying that "We can say that environmental education is the process of raising awareness of the individual against the environment, informing and ensuring its continuity" (Mrs. S.2., personal communication, December 17, 2019). Another teacher education student thought that "Environmental education is an education for the individual to recognize nature and to be aware of its environment." (Mrs. S.3., personal communication, December 16, 2019) while another one gave his opinion of this sub-theme saying that "It is all kinds of education for people to be conscious of the environment. Nature does not need us, people are made aware by the trainings that will be given because we need nature." (Mr. S.14., personal communication, December 25, 2019).

One of the teacher education students who expressed Environmental Education as "protection" indicated her opinion "Environmental education is to use it consciously after familiarizing the environment, to act by the necessary sensitivity, it is not just about stone, tree, soil, but as a whole protection (such as biosphere, lithosphere, hydrography, climatology)" (Mr. S.1., personal communication, December 16, 2019). However, another teacher education student expressed Environmental Education as an education that aims to protect the environment and take into account people's attitudes and behaviors towards nature with the sentence "The education of human beings who are in interaction with the environment to be conscious and protect the environment in order not to affect the environment more and more negatively." (Mrs. S.13., personal communication, December 25, 2019).

One of the teacher education students who describes Environmental Education as "informing" stated her opinion saying that "We can say that environmental education is the process of raising awareness of the individual against the environment, informing and ensuring its continuity." (Mrs. S.2., personal communication, December 16, 2019). Another teacher education student associates Environmental Education with knowledge, which is one of the preconditions in shaping the behaviors of an individual, and it is an education that informs the individual about the environment, and she said "[...] Environmental education is the education that allows people to be knowledgeable about their approach to the environment [...]" (Mrs. S.8., personal communication, December 23, 2019).

While Social Studies teacher education students (S.10.Mr.) and (S.14.Mr.) incompletely define Environmental Education only as awareness, protection, and sustainability; the remaining thirteen teacher education students correctly define 
Environmental Education. However, it is seen that teacher education students generally express Environmental Education as an education that raises awareness of the environment.

\section{Findings on the Concept of Ecological Literacy}

The opinions of the Social Studies teacher education students about ecological literacy were taken and it was seen that this theme consists of three sub-themes according to the data obtained. It was determined that Social Studies teacher education students define the concept of ecological literacy in three dimensions: cognitive, affective, and behavioral. The model and frequency values for this theme are shown in Figure 2.

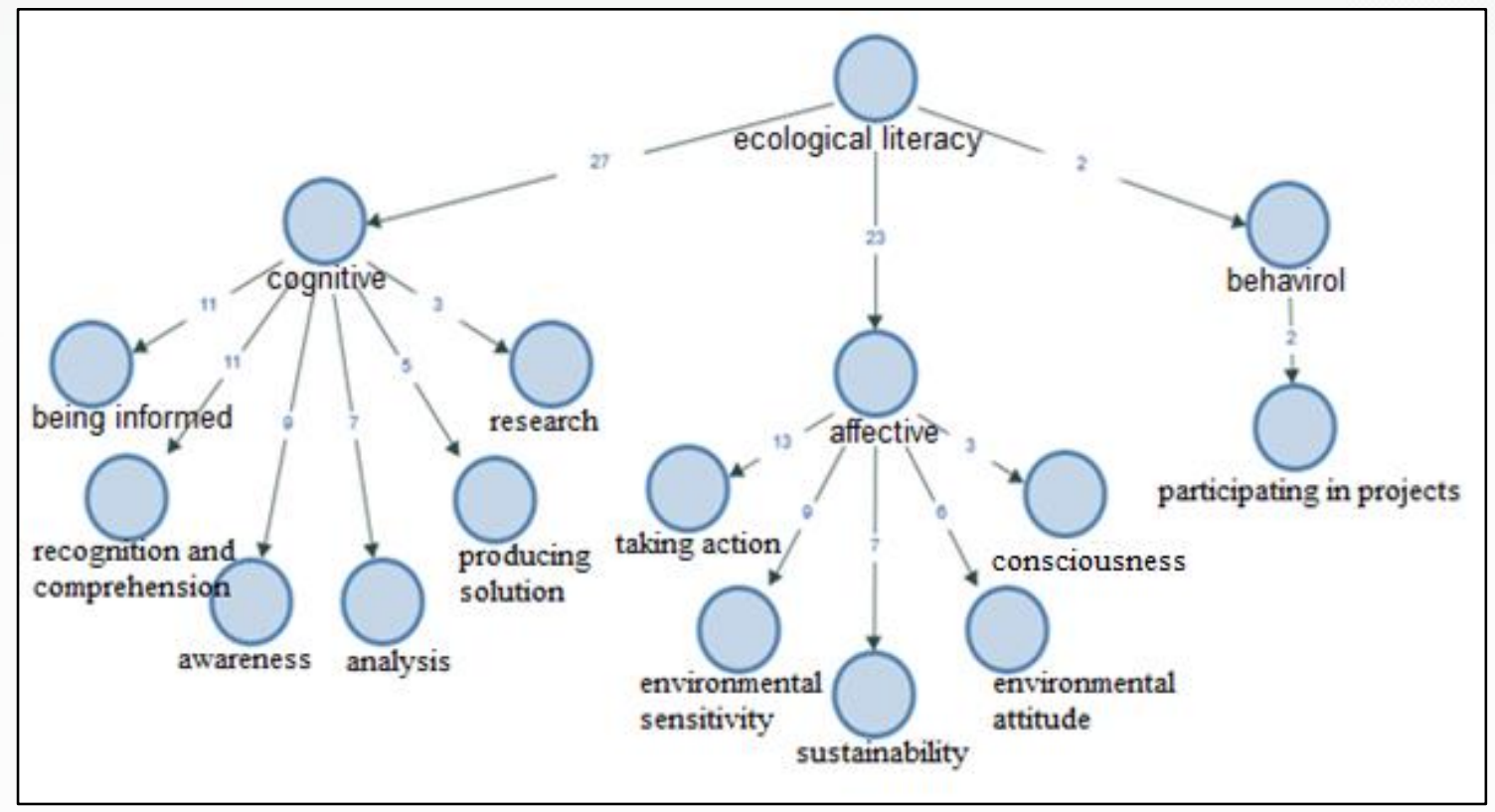

Figure 2. Model on the concept of ecological literacy

When Figure 2 is examined about ecological literacy, it is observed that it is divided into three sub-themes: "cognitive", "affective," and "behavioral", and these sub-themes are also further divided.

The most loading about ecological literacy relates to the "cognitive" theme. Teacher education students who express ecological literacy as a cognitive theme are seen to have the most loading in the sub-theme of "being informed". Other subthemes related to this theme are "recognition and comprehension", "awareness", "analysis", "producing solution" and "research". Below are some sub-themes and participant opinions regarding these data.

A teacher education student who associates ecological literacy with the subtheme of "being informed" as "cognitive" indicated her opinion that "Ecological literacy is important because it informs about how to behave living beings and nature to raise awareness about what is happening in the environment" (Mrs. S.5., personal communication, December 18, 2019). However, another teacher education student 
emphasized that ecological literacy is a state of being informed about the environment saying that "To understand how the cycles that have been around the world work and to be able to read the information that follows this process. Being ecologically literate provides us to learn more about nature." (Mrs. S.9., personal communication, December 23, 2019). One of the Social Studies teacher education students expressed ecological literacy as being related to the sub-theme of "recognition and comprehension" and recognizing and analyzing the environment and awareness about the environment with the sentence that "Ecological literacy means recognizing nature, knowing it and analyzing it more thoroughly. In short, to know nature well is to have the necessary information about nature and to be able to provide information about them." (Mrs. S.2., personal communication, December 16, 2019). In this way, it is seen that the focus is more on the cognitive dimension of ecological literacy.

Teacher education students who express ecological literacy as "affective" and with the most loading are seen to be related to sub-theme of "taking action". Other sub-themes related to this theme are; "environmental sensitivity", "sustainability", "environmental attitude" and "consciousness". Below are some sub-themes and participant opinions regarding these data.

A teacher education student who associates ecological literacy with the subtheme of "taking action" as "affective" stated his opinion that "It is to investigate environmental and human relations and to come up with ideas on these issues and to solve the environmental problems" (Mrs. S.11., personal communication, December $24,2019)$. Another teacher education student expressed ecological literacy as the situation of taking action to solve the current environmental problems with the sentence that "To be aware of the positive or negative effects of the environment and to take steps accordingly..." (Mrs. S.13., personal communication, December 25, 2019). One of the teacher education students related to the sub-theme of "environmental sensitivity" expressed ecological literacy is being sensitive to the environment, ensuring sustainability and raising awareness with the phrase that "Understanding the language of the environment, being sensitive to the environment to ensure the existence of the environment and natural environment." (Mrs. S.4., personal communication, December 17, 2019).

It is seen that teacher education students who express ecological literacy in terms of a "behavioral" perspective make a single upload to the sub-theme of "participating in projects". Below are the sub-themes and participant opinions regarding these data.

A student who associates ecological literacy with the sub-theme of "participating in projects" as "behavioral" indicated her opinion that "... participates in projects to protect its nature [...]" (Mrs. S.8., personal communication, December 23, 2019) while another teacher education student who thinks similarly with the sentence "Offering ideas to protect and improve our environment, participate in the necessary 
activities and show the respect and care to the environment in which we live." (Mr. S.10., personal communication, December 24, 2019) and addresses the behavioral dimension of ecological literacy, as well as the cognitive and affective dimensions of ecological literacy such as participating in activities related to environmental issues or developing projects, in terms of protecting and improving the environment.

While some Social Studies teacher education students [(S.12.Mrs.), (S.14.Mr.) and (S.15.Mrs.)] describe ecological literacy incompletely, and only as awareness, consciousness, recognition, and comprehension, it is seen that the remaining 12 teacher education students define ecological literacy more accurately than the students who define it incompletely. However, it is observed that when teacher education students define ecological literacy, they emphasize more cognitive and affective dimensions, and only two teacher education students address the behavioral dimension. This at some point suggests that students either ignore or inadequately understand the behavioral dimension of the concept of ecological literacy.

\section{Findings Regarding the Effects of Environmental Education on the Ecological Literacy of an Individual}

When the opinions of Social Studies teacher education students on the impact of Environmental Education on the ecological literacy of an individual were evaluated, it was determined that there are 12 different sub-themes related to the theme of Environmental Education's impact on the ecological literacy on an individual. The model and frequency values for this theme are shown in Figure 3.

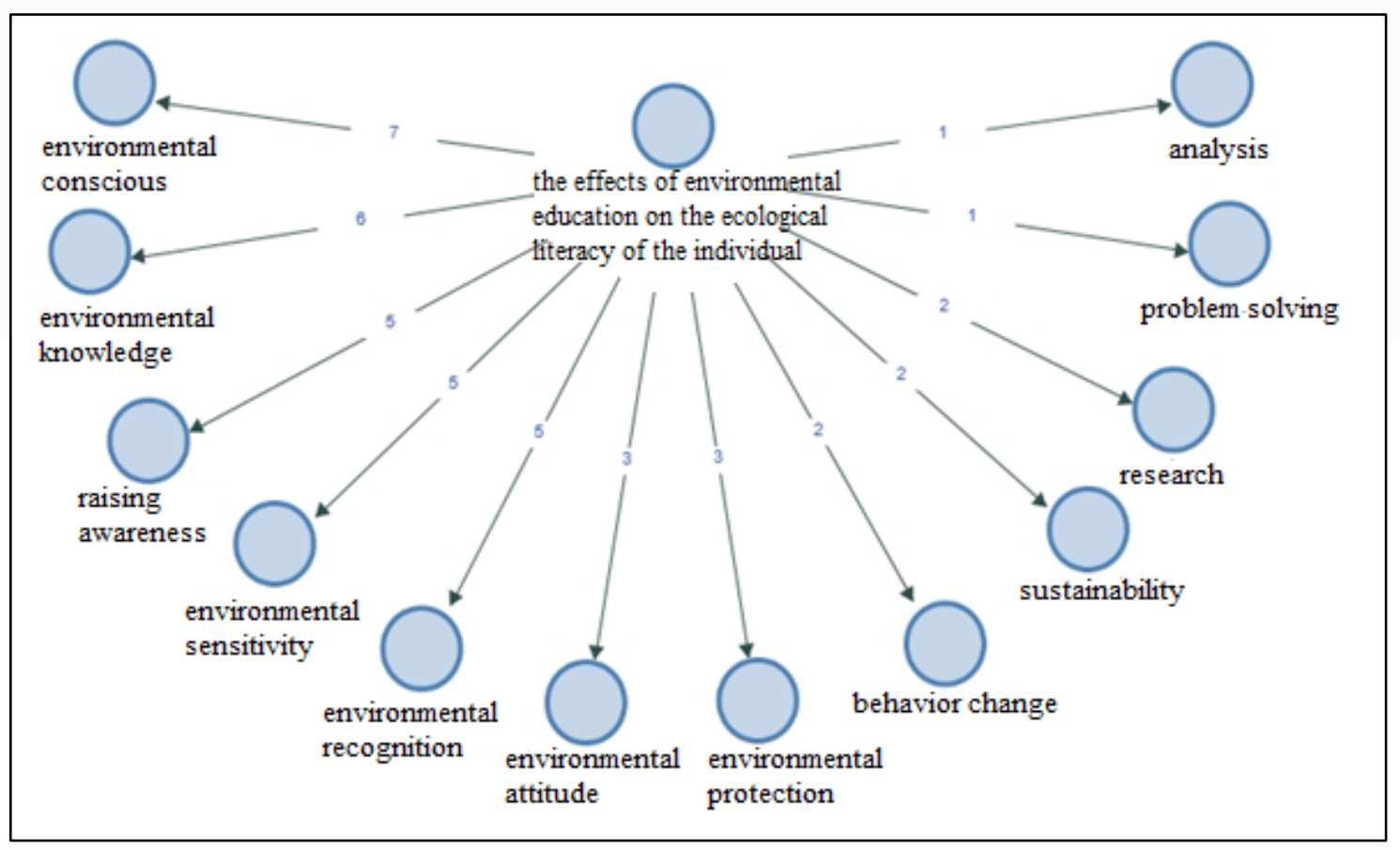

Figure 3. Model on the effects of environmental education on the ecological literacy of the individual 
When Figure 3 is examined, it is observed that the most loading is directed towards the sub-theme of "environmental conscious". Other sub-themes of environmental education related to the theme of the effects of the individual on being ecologically literate are "environmental knowledge", "raising awareness", "environmental sensitivity", "environmental recognition", "environmental attitude", "environmental protection", "behavior change", "sustainability", "research", "problem-solving", and "analysis". Below are some sub-themes and participant opinions regarding these data.

One of the teacher education students who expressed the effects of Environmental Education on the ecological literacy of an individual as being "environmental conscious" said that "Because they know the environment and nature more closely and deeply, they can raise awareness about environmental education." (Mrs. S.2., personal communication, December 16, 2019). A teacher education student expressing the opinion that environmental education is an individual's consciousness towards the environment explained her opinion with the sentence that "It is effective in raising awareness of people [...]" (Mrs. S.4., personal communication, December 17, 2019). Another teacher education student who thinks so said that "Environmental education aims to raise a conscious individual that has already a tight link between literacy and environmental education" (Mrs. S.8., personal communication, December 23, 2019) while another teacher education student expressed his opinion on this sub-theme "[...] With this acquired awareness of nature, the individual is even more curious about nature and attempts to get to know it. One of these useful attempts reveals his ecological literacy personality." (Mrs. S.9., personal communication, December 23, 2019) In this respect, it is seen that teacher education students stated that Environmental Education can be effective especially in terms of providing environmental awareness about the individual's ecological literacy.

One of the teacher education students stated her opinion about the sub-theme of "environmental knowledge" that "Environmental education gives us information about nature, environment, ecology, and ecosystem." (Mrs. S.4., personal communication, December 17, 2019). Another teacher education student expressed her opinion on this sub-theme as "Thanks to environmental education, the individual learns extra knowledge about the environment and becomes a better ecological writer [...]" (Mrs. S.8., personal communication, December 23, 2019). They associated environmental education with the individual's ecological literacy with the state of having environmental knowledge.

One of the teacher education students who expressed the effects of environmental education on the ecological literacy of an individual as "raising awareness" stated his opinion that "This lesson is effective in exposing the sense of awareness in the individual. It lets us look at the environment we have experienced and polluted before with a different eye, through a different perspective [...]" (Mr. S.10., personal communication, December 24, 2019). Another teacher education student expressed her thoughts on this sub-theme as "Because it brings individual awareness, it is trained to act to ensure continuity instead of reigning in nature." (Mrs. S.13., personal communication, December 25, 2019). Regarding this theme, it is seen that 
the teacher education students stated that the awareness of the environmental education on an individual is effective on the individual's ecological literacy.

A student who has an opinion on the sub-theme of "environmental sensitivity" expressed that "The environmental education provided not only raises awareness for the individual, but also provides its perception to be environmentally sensitive [...]" (Mrs. S.9., personal communication, December 23, 2019) while another student stated that Environmental Education has an impact on environmental sensitivity and thus is important for contributing to the ecological literacy of an individual saying that "[...] it helps to be more careful and sensitive to its environment and nature." (Mrs. S.12., personal communication, December 25, 2019).

\section{Findings Regarding the Effects of Social Studies Lessons on the Ecological Literacy of an Individual}

When the opinions of Social Studies teacher education students about the effect of Environmental Education on the ecological literacy of an individual were evaluated, it was determined that there are eight different sub-themes related to the theme of the effects of Social Studies lesson on the ecological literacy of an individual. Model frequency values regarding this theme are shown in Figure 4.

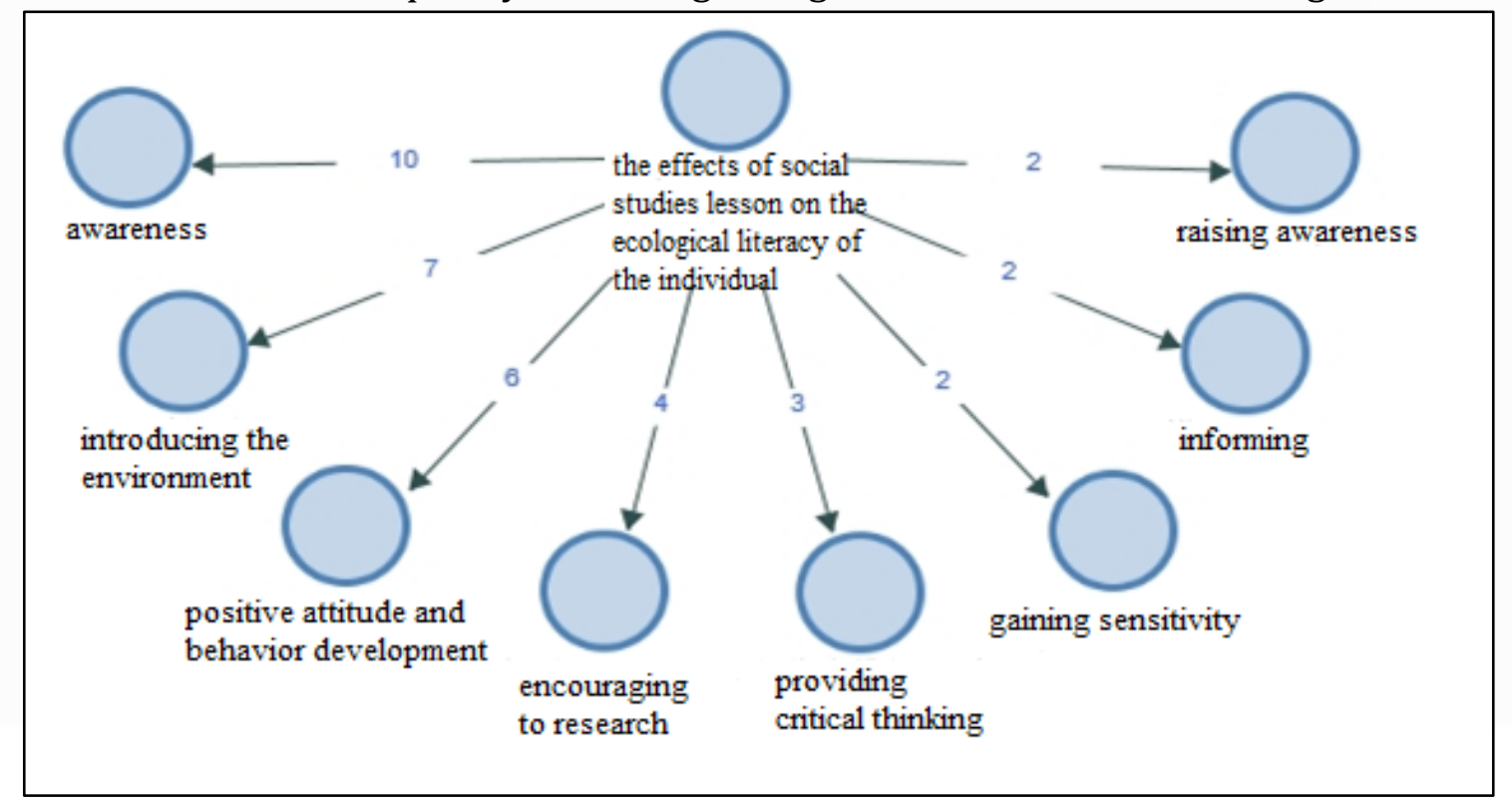

Figure 4. Model on the effects of social studies lesson on the ecological literacy of the individual

When Figure 4 is examined, it is seen that the most loading is directed towards the sub-theme of "awareness". Other sub-themes of the Social Studies lessons on the theme of the effects on an individual as being ecologically literal are "introducing the environment", "positive attitude and behavior development", "encouraging to research", "providing critical thinking", "gaining sensitivity", "informing" and "raising awareness". Below are some sub-themes and participant opinions regarding these data. 
A teacher education student who associates the effects of Social Studies lessons on the ecological literacy of an individual with the sub-theme of "awareness" stated her opinion that:

"I think the Social Studies lesson is the first step for an individual to be aware of. The social studies lesson is a stepping stone for the awareness of the natural environment, nature and history that the individual should be aware of." (Mrs. S.3., personal communication, December 17, 2019),

Whereas another teacher education student stated that Social Studies courses provide an awareness of the individual towards the environment and therefore has an important effect on ecological literacy saying that:

"The social studies lesson is active on the approach and practices of minds that are still growing towards nature and the environment. Because the world we are on is aging with the change of people and the way, it has become a war with nature, which threatens the extinction of the living species. It is effective on the awareness activities that the individual has done to adapt to nature and increase its continuity by being aware of this." (Mrs. S.13., personal communication, December 25, 2019).

While a teacher education student who associates the effects of Social Studies lessons on the ecological literacy of an individual with the sub-theme of "introducing the environment" stated that it is important for the individual to get to know the environment of the Social Studies course and to realize the natural elements experienced in their environment and the relationship between them saying that:

"Environmental literacy, which is among the knowledge, skills, attitudes and values we have acquired in the social studies lesson, has been acquired about recognizing and knowing the environment and how we should behave. In addition to environmental literacy, ecological literacy has enabled us to obtain information about the living things that live in there and their environment." (Mrs. S.5., personal communication, December 18, 2019).

Another teacher education student who thought the same way explained his opinion with the sentence that "Social studies is effective in recognizing the individual first, and then the environment and society in which one lives [...]" (Mr. S.10., personal communication, December 24, 2019). Another teacher education student, on the other hand, emphasized that the role of Social Studies lessons are very important for the individual to be ecologically literate, and it can be quite effective to realize the environment in which the individual lives through Social Studies lesson saying that "The main purpose of social studies is for individuals to recognize and protect the environment in which they live. Therefore, it must be taken a good social studies lesson to be ecologically literate." (Mr. S.11., personal communication, December 24, 2019).

One of the teacher education students who expressed her opinion on the subtheme of "positive attitude and behavior development" said that "Environmental literacy, which is among the knowledge, skills, attitudes and values we have acquired in the social studies lesson, has been acquired about recognizing and knowing the environment and how we should behave [...]" (Mrs. S.5., personal communication, December 18, 2019), while another teacher education student who thinks similarly that Social Studies lessons have a positive effect on ecological literacy in terms of not 
only getting to know the environment in which the students are but also developing other positive attitudes and behaviors that affect them expressed her opinion in the sentence "[...] examines, learns and gets to know his environment better, perceives, protects and tries to prevent possible damages. "(Mrs. S.12., personal communication, December 25, 2019).

A teacher education student who has an opinion on the sub-theme of "encouraging to research" expressed her opinion that:

\footnotetext{
"Social information is an interdisciplinary course where many lessons come together. Therefore, many lessons are mentioned in its content. Features in the fields of history, geography, people's curiosity is increasing and pushing them to literacy to better understand, learn and analyze it. Thus, it directs to conduct deeper and more informative researches [...]" (Mrs. S.2., personal communication, December 16, 2019).
}

However, another teacher education student stated that the Social Studies lessons aroused curiosity in terms of learning environmental factors and directed the individual to research, therefore it could be effective in the development of the individual's ecological literacy saying that "[...] the individual also wants to understand nature, and the instinct of curiosity brought by the social studies lesson keeps him/her in the world as ecologically literal." (Mrs. S.9., personal communication, December 23, 2019)..

\section{Result and Discussion}

It has been seen that opinions from Social Studies teacher education students about the impact of Environmental Education on ecological literacy express Environmental Education as an education to raise awareness, protect, inform, and develop sustainability and sensitivity in the individual overall. This shows that students in general correctly define Environmental Education. Similarly, the study conducted by Özmen \& Özdemir (2016) related to the Environmental Education of teacher education candidates; it was seen that they have been given answers that is a lesson which gives people information about the environment and nature, raises awareness of society on environmental issues, and increases sensitivity on environmental issues.

It has been observed that students touch on the most cognitive aspect of the concept of ecological literacy. They expressed that ecological literacy is being informed, recognition and comprehension, awareness, analysis, producing, and research as cognitively; it is taking action, environmental sensitivity, sustainability, environmental attitude, consciousness as affectively; it is participating in projects as behaviorally. When explaining the concept of ecological literacy, it is seen that teacher education candidates are more involved in the cognitive dimension, and compared to this, they mention less about the affective dimension. It was determined that only two teacher education students addressed the behavioral dimension. This suggests that at some point students ignore the behavioral dimension of the concept of ecological literacy. Similarly, in the study by Aydin et al., (2016), it is seen that Social Studies teacher education students expressed their opinions on the concept of ecological literacy that nature has a correct understanding and awareness of the environment. In the study conducted by 
Karatekin (2011a), the level of environmental literacy of Social Studies teacher education candidates varies according to the dimensions that constitute environmental literacy. Environmental knowledge and environmental behavior of teacher education candidates were found to be moderate, their affective tendencies towards the environment were found to be high and their cognitive skills were found to be low.

It has been reached that teacher education students expressed that the effects of Environmental Education on an individual's becoming ecologically literate were effective in gaining and developing skills, values, attitudes and behaviors in terms of environmental consciousness, environmental knowledge, raising awareness, environmental sensitivity, environmental recognition, environmental attitude, environmental protection, behavior change, sustainability, research, problem solving and analysis. Similarly, in the study conducted by Kıyıcl et al. (2014), it was seen that nature education has effects such as environmental consciousness and environmental awareness on individuals.

It was concluded that the effects of Social Studies lessons on the ecological literacy of an individual can be effective in terms of awareness, introducing the environment, positive attitudes and behavior development, encouraging to research, providing critical thinking, gaining sensitivity, informing and raising awareness.

When the literature is examined, it is seen that studies are carried out on the concept of Environmental Education and ecological literacy. In the study conducted by Atasoy \& Ertürk (2008), it was shown that the environmental knowledge and environmental attitudes of primary school students were not sufficient and the reasons for this were inadequate teaching techniques in the school. Kurtdede-Fidan \& Thessical-Moon (2016) stated that teacher education candidates should be informed about practical environmental literacy in teacher training programs in the study conducted to determine students' views on practical environmental literacy activities and the effects of these activities on students' responsible environmental behavior. In the study conducted by Şahin et al. (2016), it was stated that the teacher education candidates should be given environmental education courses by the content of the departments to gain knowledge, skills, and values for the environment. In the study conducted by Teksöz et al. (2010), environmental knowledge determining environmental literacy, attitude towards the environment, environmental uses, and interest in environmental problems were evaluated and it was seen that the environmental knowledge scores of the teacher education candidates were insufficient..

\section{Suggestions}

Environmental problems are increasing worldwide due to the rapid depletion of natural resources combined with the degradation and contamination of thousands of ecosystems occurring as a result of population growth. The most important solution to these problems is the spread of environmental education which aims to provide knowledge, attitudes, behavior, and skills related to human-nature interaction and environmental problems. Environmental Education has positive effects on the ecological literacy of an individual in terms of informing and raising 
awareness about research, analysis, and problem-solving for sustainability which ultimately leads to behavioral change with a positive attitude and development. Therefore, the concepts of Environmental Education and ecological literacy should be emphasized because it is known that environmental problems will continue to increase and there is a need for ecologically literate individuals who can be effective for life. For the existence of a sustainable environment, Environmental Education should be considered at all levels of education, and students should be focused on gaining ecological literacy skills. Environmental Education should not only reflect environmental problems but also include training to prevent problems before they arise in an environment, and promote sustainable practice. For this reason, it is necessary to be ecologically literate and bring such awareness to students, thought the conduct of explanations and projects. The professional development of teacher candidates who will provide Environmental Education to students, and therefore help them to gain ecological literacy skills and develop their practice as an ecologically literate person should also be supported.

\section{References}

Adanall, R. \& Alım, M. (2019). The students' behaviours at the instructional geocaching applied in problem-based environmental education. Review of International Geographical Education Online (RIGEO), 9(1), 122-148, Retrieved from http://www.rigeo.org/vol9no1/Number1Spring/RIGEO-V9-N1-6.pd

Atasoy, E. \& Ertürk, H. (2008). A field study about environmental knowledge and attidudes of elementary scool students. Erzincan Üniversitesi Eğitim Fakültesi Dergisi, 10(1), 105-122.

Retrieved

from https://dergipark.org.tr/tr/pub/erziefd/issue/6003/80053

Atasoy, E. (2005). Environmantal education: A study for elementary school students' environmental attitude and knowledge (Unpublished doctoral dissertation). Uludağ Üniversitesi Sosyal Bilimler Enstitüsü, Bursa.

Atasoy, E. (2019). İnsan doğa etkileşimi ve çevre için eğitim. Bursa: Sentez Yayıncılık.

Aydın, M., Dündar, R. \& Korkut, Ş. (2016). Teacher views upon ecological literacy education in turkey. Abant İzzet Baysal Üniversitesi Eğitim Fakültesi Dergisi, 16(USBES Özel Sayı II), 1160-1172. Retrieved from http://ekolojikokuryazarim.com/images/ makaleler/T\%C3\%9CRK\%C4\%B0YE\%E2\%80\%99DE\%20EKOLOJ\%C4\%B0K\%200 KURYAZARLIK\%20E\%C4\%9E\%C4\%B0T\%C4\%B0M\%C4\%B0NE.pdf

Bahar, M. \& Kiras, B. (2017). General analysis of articles and thesis on environmental education which were published in turkey. Abant İzzet Baysal Üniversitesi Ĕgitim Fakültesi Dergisi, 17(4), 1702-1720. Retrieved from https://doi.org/10.17240/ aibuefd. 2017.17.32772-363962

Büyüköztürk, Ş., Kılıç Çakmak, E., Akgün, Ö. E., Karadeniz, Ș. \& Demirel, F. (2019). Eğitimde Bilimsel Araştırma Yöntemleri. Ankara: Pegem Akademi.

Cilesiz, S. (2011). A phenomenological approach to experiences with technology: Current state, promise, and future directions for research. Educational Technology Research and Development, 59, 487-510. Retrieved from https://doi.org/10.1007/s11423010-9173-2

Creswell, J.W. (2019). Eğitim Araştırmaları: Nicel ve Nitel Araştırmanın Planlanması, Yürütülmesi ve Değerlendirilmesi. (H. Ekşi, Trans. Ed.), İstanbul: Eğitim Danışmanlığı ve Araştırmaları Merkezi. (Original work published 2012). 
Creswell, J.W. (2020). Nitel Araștırma Yöntemleri: Beş Yaklaşıma Göre Nitel Araştırma ve Araştırma Deseni. (M. Bütün \& S. B. Demir Trans. Eds), Ankara: Siyasal Kitabevi. (Original work published 2013).

Dada, D., Eames, C. \& Calder, N. (2017). Impact of environmental education on beginning preservice teachers' environmental literacy. Australian Journal of Environmental Education, 33(3), 201-222. Retrieved from https://doi.org/10.1017/aee.2017.27

Erciş, A. \& Türk, B. (2016). In the frame of ethics consumption, consumer and the environment: the moderator role of ecoliteracy. Cukurova Üniversitesi Íktisadi ve İdari Bilimler Fakültesi Dergisi, 20(2), 1-24. Retrieved from https://dergipark.org.tr/ en/pub/ cuiibfd/issue/34645/385945

Erlandson, D. A., Harris, E. L., Skipper, B. L. \& Allen, S. T. (1993). Doing naturalistic inquiry: A guide to methods. Baverly Hills, CA: Sage.

Garipağaoğlu, N. (2020). The approaches of turkish geographers to environmental issues and studies in the field. Türkiye Araștırmaları Literatür Dergisi, 18(35), 5-45. Retrieved from https://dergipark.org.tr/en/pub/talid/issue/55005/754725

Güler, T. (2010). The effects of an ecology based environmental education on teachers' opinions about environmental education. Eğitim ve Bilim, 34(151), 30-43. Retrieved from http://egitimvebilim.ted.org.tr/index.php/EB/article/view/606

Hart, P. (1987). The Educational Context: Environmental Education in the School Curriculum. Disinger, John F., Comp. (Ed.), Trends and Issues in Environmental Education: EE in School Curricula. Reports of a Symposium and a Survey. Environmental Education Information Reports. Office of Educational Research and Improvement (ED). Retrieved from https://eric.ed.gov/?id=ED292608

Kahyaoğlu, M., Daban, Ş. \& Yangın, S. (2008). Attitudes of primary candidate teachers about environmental. Dicle Üniversitesi Ziya Gökalp Eğitim Fakültesi Dergisi, (11), 42-52. Retrieved from https://dergipark.org.tr/en/pub/zgefd/issue/47957/606768

Karataş, A. (2018). Çevre eğitiminin tarihsel kökenleri. R. Sever \& E. Yalçınkaya (Eds). Çevre Ĕgitimi (ss. 21-35). Ankara: Pegem Akademi.

Karatekin, K. (2011a). The determination of environmental literacy levels of pre-service teachers of social studies (Unpublished doctoral dissertation). Gazi Üniversitesi Sosyal Bilimler Enstitüsü, Ankara.

Karatekin, K. (2011b). Sosyal bilgilerde çevre eğitimi. R. Turan, A. M. Sünbül \& H. Akdağ (Eds). Sosyal Bilgiler Öğretiminde Yeni Yaklaşımlar II (pp. 270-285). Ankara: Pegem Akademi.

Kaya, N., Çobanoğlu, M., \& Artvinli, E. (2011). Environmental education studies in the world and turkey for sustainable development. 6. Ulusal Coğrafya Sempozyumu, 407-417. Retrieved from http://tucaum.ankara.edu.tr/wp-content/uploads/sites/280/2015/ 08/semp6_44.pdf

Kıyıcl, F. B., Yiğit, E. A. \& Darçın, E. S. (2014). Investigation of pre-service teacher's opinion and environmental literacy level change with nature education. Trakya Üniversitesi Eğitim Fakültesi Dergisi, 4(1), 17-27. Retrieved from https://dergipark.org.tr/ en/pub/trkefd/issue/21473/230150

Kostova, Z. \& Atasoy, E. (2008). Methods of successful learning in environmental education. Online Submission, 4(1), 49-78. Retrieved from https://eric.ed.gov/?id=ED502021 
Kurtdede-Fidan, N. \& Selanik-Ay, T. (2016). Acquisition of operational environmental literacy in social studies course. International Journal of Environmental and Science Education, 11(13), 5951-5968. Retrieved from https://eric.ed.gov/?id=EJ1115521

Mercan, S. I. (2019). Sosyal bilgiler öğretiminde çevre eğitimi. T. Çelikkaya, Ç. Ö. Demirbaş, T. Yıldırım \& H. Yakar (Eds). Yeni Program ve Ders içeriklerine Göre Sosyal Bilgiler Öğretimi I (pp. 373-398). Ankara: Pegem Akademi.

Miles, M.B. \& Huberman, A.M. (2019), Genişletilmiş bir kaynak kitap: Nitel veri analizi. S. Akbaba Altun \& A. Ersoy (Trans. Eds.), Ankara: Pegem Akademi. (Original work published 1994).

Moser, A. \& Korstjens, I. (2018). Series: Practical guidance to qualitative research. Part 3: Sampling, data collection and analysis, European Journal of General Practice, 24(1), 918. Retrieved from https://doi.org/10.1080/13814788.2017.1375091

North American Association for Environmental Education (NAAEE). (19.03.2019). Professional Development of Environmental Educators: Guidelines for Excellence. Retrieved from https://naaee.org/eepro/publication/guidelines-professionaldevelopment-environmental-educators

Özdemir, O. (2007). A new environmental education perspective: "Education for sustainable development". Eğitim ve Bilim, 32(145), 23-39. Retrieved from http://eb.ted.org.tr/index.php/EB/article/view/813

Özdemir, O. (2017). Ekolojik okuryazarlık ve çevre eğitimi. Ankara: Pegem Akademi.

Özmen, H. \& Özdemir, S. (2016). Determination of pre-service science and technology teachers' views on environmetal education. Kastamonu Education Journal, 24(4), 1691-1712. Retrieved from https://kefdergi.kastamonu.edu.tr/index.php/ Kefdergi/article/view/496

Patton, M.Q. (2018). Nitel Araştırma ve Değerlendirme Yöntemleri. (M. Bütün \& S. B. Demir, Trans. Eds.). Ankara: Pegem Akademi. (Original work published 2000).

Peyton, B., Campa, H., Winterstein, S. R., Peyton, M.D. \& Peyton, J.V. (1995). Biological diversity for secondary education: environmental education module. UNESCO-UNEP International Environmental Education Programme (IEEP), 1-152. Retrieved from https://unesdoc.unesco.org/ark:/48223/pf0000111306

Powell, R. B., Stern, M. J., Frensley, B. T. \& Moore, D. (2019). Identifying and developing crosscutting environmental education outcomes for adolescents in the twenty-first century (EE21). Environmental Education Research, 25(9), 1281-1299. Retrieved from https://doi.org/10.1080/13504622.2019.1607259

Roth, C. E. (1992). Environmental Literacy: Its roots, evolution, and directions in the 1990s. Columbus, OH: ERIC Clearinghouse for Science, Mathematics, and Environmental Education. Retrieved from https://eric.ed.gov/?id=ED348235

Saban, A. (2009). Prospective teachers' mental images about the concept of student. Türk Eğitim Bilimleri Dergisi, 7(2), 281-326. Retrieved from https://dergipark.org.tr/en/pub/tebd/issue/26107/275061

Şahin, S., Ünlü, E. \& Ünlü, S. (2016). Investigation of teacher candidates' environmental literacy awareness level. Education Sciences, 11(2), 82-95. Retrieved from http://dx.doi.org/10.12739/NWSA.2016.11.2.1C0655

Sever, R. \& Yalçınkaya, E. (2018). Çevre eğitimine genel bir bakış ve temel kavramlar. R. Sever \& E. Yalçınkaya (Eds). Çevre Eğitimi (pp. 2-17). Ankara: Pegem Akademi. 
Tavşancıl, E. \& Aslan, E. (2001). Sözel, yazılı ve diğer materyaller için içerik analizi ve uygulama örnekleri. İstanbul: Epsilon Yayıncılık.

Teksöz, G., Şahin, E. \& Ertepınar, H. (2010). Environmental literacy, pre-service teachers, and a sustainable future. Hacettepe Üniversitesi Eğitim Fakültesi Dergisi, 39(39), 307320. Retrieved from http://efdergi.hacettepe.edu.tr/yonetim/icerik/makaleler/480published.pdf.

Ulu-Kalın, Ö. (2018). Çevre eğitimi okuryazarlığı. R. Sever \& E. Yalçınkaya (Eds). Çevre Ĕ̆itimi (pp. 199-225). Amkara: Pegem Akademi.

Yıldırım, A. \& Şimşek, H. (2018). Sosyal bilimlerde nitel araştırma yöntemleri. Ankara: Seçkin Yayıncilık.

\section{Biographical Statements}

Esen DURMUŞ is a faculty member who is an Assoc. Prof. in The Social Studies Education Program of the Department of Turkish and Social Sciences Education at Firat University Faculty of Education. She completed his undergraduate education in Firat University Department of Arts and Sciences Geography (1998), his master's degree in Geography department of Firat University Institute of Social Sciences, Turkish Geography Program (2001), and her Ph.D. in The Department of Geography of Firat University Institute of Social Sciences (2009). In the years 2003-2009, she worked as a research assistant in the Department of Geography of Firat University Institute of Social Sciences. From 2009 to 2019, she worked as an Assistant Professor at Firat University Faculty of Education, Department of Turkish and Social Sciences Education, Department of Social Studies Education. As of 2019, she continues to work as an Associate Doctor in the Department of Social Studies Education in The Turkish and Social Sciences Education Department of Firat University Faculty of Education. She also has national and international studies in the fields of regional geography, Geography of Turkey, and social studies education..

Müșerref Kubra KINACI is a Ph.D. student in the field of Social Studies Education at Frrat University. She completed his undergraduate education (2012) at Frrat University, Social Studies Teaching undergraduate program. She also completed his master's degree (2018) in Social Education at the same university. The subject of the master's thesis is to determine "The views of pre-service social studies teachers on values education and values included in social studies curriculum". Her current research is on social studies lessons, environmental education for social studies teachers and teacher candidates, value education, nature trips, and historical empathy.. 